\title{
Effective short term treatment of Paget's disease with oral etidronate
}

\author{
C J PRESTON, A J P YATES, M N C BENETON, R G G RUSSELL, R E S GRAY, \\ $R$ SMITH, J A KANIS
}

\begin{abstract}
Twelve patients with Paget's disease of bone were treated with high doses of disodium etidronate for one month and compared with patients given treatments for longer periods. The effects of treatment for one month with etidronate $20 \mathrm{mg} / \mathrm{kg}$ daily were indistinguishable from six months' continuous treatment with the same dose but significantly better than treatment with $5 \mathrm{mg} / \mathrm{kg}$ daily in suppressing biochemical indices of disease activity. Treatment for one month was associated with transient osteomalacia but sustained suppression of bone resorption.

Short term treatments with high doses of disodium etidronate may maximise suppression of disease activity but decrease exposure to unwanted effects.
\end{abstract}

\section{Introduction}

The diphosphonate disodium etidronate is now widely available as an effective drug for the clinical management of patients with Paget's disease of bone.' The choice of dose and duration of treatment pose several problems. Thus the recommended daily dose of $5 \mathrm{mg} / \mathrm{kg}$ given by mouth for three to six months is ineffective in suppressing disease activity in some patients, ${ }^{2}$ presumably because insufficient drug is absorbed from the intestinal tract. In others similar doses may induce unwanted effects more usually associated with higher doses. ${ }^{34}$ High doses $(10-20 \mathrm{mg} / \mathrm{kg}$ daily) given for three

\footnotetext{
Department of Human Metabolism and Clinical Biochemistry, University of Sheffield Medical School, Sheffield S10 2RX

C J PRESTON, MIBIOL senior chief medical laboratory scientific officer A J P YATES, MB, MRCP, clinical research fellow

$M$ N C BENETON, HNC, DVES, research technician

R G G RUSSELL, FRCP, MRCPATH, professor and head of department

R E S GRAY, MB, MRCP, clinical research fellow

J A KANIS, FRCP, MRCPATH, reader

Nuffield Orthopaedic Centre, Oxford OX3 7LD

R SMITH, MD, FRCP, consultant physician in metabolic medicine

Correspondence to: Dr Kanis.
}

to six months reduce the increased bone turnover more completely and in more patients than lower doses but may impair mineralisation of bone. ${ }^{25}$

We found that shorter periods of treatment induced long remissions comparable with those achieved by treatment with high doses for six months. We report the effects of using a high dose of disodium etidronate $(20 \mathrm{mg} / \mathrm{kg}$ daily) for one month.

\section{Patients and methods}

We studied 12 patients with biochemical and radiographic evidence of Paget's disease of bone. All patients had active Paget's disease, as judged by increased activity of serum alkaline phosphatase, and none had received treatment other than analgesics in the 12 months before the study. All patients gave informed consent and the study was approved by the local ethics committee. Disodium etidronate was given for one month in a single daily dose of $20 \mathrm{mg} / \mathrm{kg}(80 \mu \mathrm{mol} / \mathrm{kg})$ by mouth without food. Blood and two hourly urine samples were collected under fasting conditions before treatment, weekly during treatment, and monthly thereafter for measurement of serum phosphate concentration, alkaline phosphatase activity, and the ratio of urinary hydroxyproline to creatinine using a Technicon autoanalyser. ${ }^{6}$

Five patients had biopsy specimens of transiliac bone taken before and four to 12 months after completing treatment, and four others had a biopsy specimen taken two weeks after starting treatment. Biopsy specimens were taken under local anaesthesia using an $8 \mathrm{~mm}$ Meunier transiliac trephine and processed for quantitative histology using methods previously described. ${ }^{6}$ The biochemical results for this group of patients were compared with those for 41 patients previously treated with disodium etidronate $20 \mathrm{mg} / \mathrm{kg}$ daily and 14 patients treated with $5 \mathrm{mg} / \mathrm{kg}$ daily continuously for six months. ${ }^{5}$

Measurements of alkaline phosphatase activity were log transformed for statistical comparison. The mean values and the estimates of dispersion $( \pm$ SEM) were antilogged for presentation. When percentage changes in alkaline phosphatase activity were analysed untransformed data were used. Comparisons between mean values were assessed using Student's $t$ test for paired data or two way analysis of variance, as appropriate.

\section{Results}

Treatment with disodium etidronate for one month reduced excretion of urinary hydroxyproline to 40 (5)\% (mean (and SEM)) of initial values. Serum activity of alkaline phosphatase, however, did not change significantly during treatment but decreased thereafter. During the five months after 
treatment was stopped urinary hydroxyproline and serum alkaline phosphatase values continued to fall and reached $32(4) \%$ and $39(5) \%$ of initia values respectively. These biochemical responses to treatment were similar to those seen in patients receiving disodium etidronate $20 \mathrm{mg} / \mathrm{kg}$ daily continuously for six months but significantly better than those in patients treated with the lower dose $(5 \mathrm{mg} / \mathrm{kg})$ for six months $(\mathrm{p}<0.0001, \mathrm{p}<0.001$, respectively, table I). In addition, the $5 \mathrm{mg}$ dose induced a less consisten response than higher doses (Bartlett's test for homogeneity of variance), but as with higher doses disease activity remained biochemically suppressed after disodium etidronate was withdrawn.
The dose of disodium etidronate currently recommended for Paget's disease is $5-10 \mathrm{mg} / \mathrm{kg}$ daily for three to six months, but this may not be an optimum dose for all patients, even though most may respond satisfactorily. Bone pain, increased radiotranslucency on $x$ ray pictures, and microfocal osteomalacia have been reported in some centres. ${ }^{34}$ Many of these patients had pronounced hyperphosphataemia during treatment, which appears to be associated in other centres only with the use of larger doses. ${ }^{15}$ In contrast, others have shown the dose of $5 \mathrm{mg} / \mathrm{kg}$ daily to be fairly ineffective ( $M$

TABLE I-Details of treatment with disodium etidronate and response of serum alkaline phosphatase expressed as mean values

\begin{tabular}{|c|c|c|c|c|c|}
\hline \multirow[b]{3}{*}{ Treatment regimen } & \multicolumn{5}{|c|}{ Serum alkaline phosphatase activity (IU/l) } \\
\hline & \multirow[b]{2}{*}{ Before treatment (range) } & \multicolumn{2}{|c|}{ At 6 months } & \multicolumn{2}{|c|}{ At 1 year } \\
\hline & & Activity ( \pm SEM) & $\begin{array}{c}\text { Mean }(\mathrm{SD}) \% \text { of } \\
\text { initial concentration }\end{array}$ & Activity $( \pm$ SEM $)$ & $\begin{array}{c}\text { Mean (SD)\% of } \\
\text { initial concentration }\end{array}$ \\
\hline $\begin{array}{l}20 \mathrm{mg} / \mathrm{kg} \text { for } 1 \text { month } \\
20 \mathrm{mg} / \mathrm{kg} \text { for } 6 \text { months } \\
5 \mathrm{mg} / \mathrm{kg} \text { for } 6 \text { months }\end{array}$ & $\begin{array}{l}348(274-443) n=12 \\
309(273-350) n=41 \\
305(254-366) n=14\end{array}$ & $\begin{array}{l}125(101-155) n=12 \\
116(104-130) n=38 \\
132(100-174) n=12\end{array}$ & $\begin{array}{l}39(17)^{\star \star} \\
44(25)^{\star \star} \\
58(49)\end{array}$ & $\begin{array}{l}105(82-136) n=10 \\
141(119-167) n=29 \\
110(80-150) n=10\end{array}$ & $\begin{array}{l}36(20)^{\star} \\
56(31) \\
56(47)\end{array}$ \\
\hline
\end{tabular}

Significance of differences in variance between the $5 \mathrm{mg} / \mathrm{kg}$ dose and the high dose regimens: ${ }^{\star} \mathrm{p}<0 \cdot 02 ;{ }^{\star \star} \mathrm{p}<0 \cdot 01$.

Eleven of the 12 patients had bone pain attributed to Paget's disease, which had improved considerably in eight patients at six months. No patient developed bone pain or sustained a fracture. Serum phosphate concentration rose progressively throughout treatment (from $1.04(0.03) \mathrm{mmol} / \mathrm{l}(3.22$ $(0.09) \mathrm{mg} / \mathrm{dl})$ to $1.67(0.08) \mathrm{mmol} / \mathrm{l}(5.17(0.25) \mathrm{mg} / \mathrm{dl}) ; \mathrm{p}<0.001)$ and reversed when treatment was stopped. Examination of biopsy specimens of bone showed that mineralisation was halted during treatment and was associated with an increase in osteoid thickness and volume. These changes were not observed in biopsy specimens taken after treatment was stopped (table II).

TABLE II-Mean (SEM) histological measurements in trabecular bone in Paget's disease before, during, and after treatment with etidronate

\begin{tabular}{|c|c|c|c|}
\hline & $\begin{array}{l}\text { Before treatment } \\
\qquad(n=5)\end{array}$ & $\begin{array}{l}\text { During treatment } \\
\qquad(\mathrm{n}=4)\end{array}$ & $\begin{array}{l}\text { After treatment } \\
\qquad(\mathrm{n}=5)\end{array}$ \\
\hline Osteoid area ( $\%$ matrix area) & $5 \cdot 8(1 \cdot 6)$ & $14 \cdot 6(1 \cdot 8)^{\star}$ & $7 \cdot 3(2 \cdot 4)$ \\
\hline $\begin{array}{l}\text { Osteoid surface (\% total trabecular } \\
\text { surface) }\end{array}$ & $46 \cdot 3(5 \cdot 7)$ & $59 \cdot 6(8 \cdot 8)$ & $47 \cdot 2(7 \cdot 3)$ \\
\hline Mean width of osteoid seam $(\mu \mathrm{m})$ & $12 \cdot 7(1.5)$ & $21 \cdot 3(4 \cdot 4)^{\star}$ & $13 \cdot 3(1.9)$ \\
\hline $\begin{array}{l}\text { Calcification front (\% osteoid } \\
\text { surface) }\end{array}$ & $55 \cdot 6(2 \cdot 0)$ & $27 \cdot 6(18 \cdot 6)^{\star}$ & $48 \cdot 6(3 \cdot 8)$ \\
\hline $\begin{array}{l}\text { Osteoclast surface (\% total } \\
\text { trabecular surface) }\end{array}$ & $4 \cdot 6(0 \cdot 7)$ & Not determined & $1 \cdot 3(0 \cdot 8)^{\star}$ \\
\hline
\end{tabular}

\section{Discussion}

These results showed that disodium etidronate $(20 \mathrm{mg} / \mathrm{kg}$ daily $)$ given for only one month suppressed the biochemical indices of disease activity in Paget's disease. The response was similar to that seen during longer treatments using the same dose, and the remission continued for at least one year. Although the patients given the longer treatments were not studied concurrently or randomly allocated to the three treatment regimens, the groups were reasonably matched before treatment for alkaline phosphatase activity (see table I), which is one of the major factors determining the degree of response observed. There appears to be little benefit, therefore, in giving the $20 \mathrm{mg} / \mathrm{kg}$ dose for longer than one month or giving repeated short courses of disodium etidronate to maintain suppression of disease activity.

The use of high doses of etidronate for long periods is associated with impaired mineralisation of bone. ${ }^{5}$ The patients we treated for one month also showed increased amounts of osteoid owing to a delay in mineralisation, but this was reversed when treatment was stopped (see table II), suggesting that the short treatment regimen reduces the length of patients' exposure to this unwanted effect.
Peacock, personal communication). In our own experience this dose is clearly effective but gives less consistent responses than higher doses, probably because of the low and variable absorption of the drug in the gut and the disease activity itself, which may influence the amount of drug available at Pagetic and other skeletal sites. ${ }^{78}$

The rise in serum phosphate concentration induced by high doses of disodium etidronate is not associated with any known untoward effects. ${ }^{9}$ The effect is much less pronounced with lower doses and can best be exploited, therefore, by using high doses for short periods, as a rise in serum phosphate concentration provides a reliable index of compliance or the adequacy of absorption.

We conclude that high doses of disodium etidronate given for one month induce suppression of disease activity comparable to that observed after longer treatments. This regimen gives more consistent effects than lower doses. Although treatment impairs the mineralisation of bone, the impairment is transient. Further studies of larger numbers of patients are needed to determine the duration of remission induced by short treatments, but this regimen can tentatively be recommended as an effective alternative to those currently used.

We thank the National Association for the Relief of Paget's disease and Norwich Eaton Pharmaceutical Industries for supporting our work. AJPY is a Medical Research Council clinical research fellow, and RESG and MNB are supported by the Leukaemia Research Fund and National Kidney Research Fund. We thank Linda Westlake for statistical advice and Dr A R W Forrest for his help in providing biochemical assays.

\section{References}

1 Kanis JA, Russell RGG. Diphosphonates and Paget's disease of bone. Met Bone Dis Relat Res 1981;3:4-5.

2 Altman RD, Johnson CC Jr, Khairi MRA, Wellman H, Serafini AN, Sankey RR. Influence of sodium etidronate on clinical and laboratory manifestation of Paget's disease (osteitis deformans). N Engl f Med 1973;289:1379-84.

3 Boyce BF, Smith L, Fogelman I, Johnston E, Ralston S, Boyle IT. Focal osteomalacia due to low dose diphosphonate therapy in Paget's disease. Lancet 1984;i:821-4.

Nagant de Deuxchaisnes C, Rombouts-Lindermans C, Huaux JP, Devogelaer JP. Diphosphonate and inhibition of bone mineralisation. Lancet 1982;ii:607-8.

5 Russell RGG, Smith R, Preston C, Walton RJ, Woods CG. Diphosphonates in Paget's disease. Lancet 1974;i:894-8.

6 Yates AJP, Percival RC, Gray RES, et al. Intravenous clodronate in the treatment and retreatment of Paget's disease of bone. Lancet 1985;i:1474-7.

7 Fogelman I, Smith ML, Mazess R, Bevan JA. Absorption of diphosphonate in normal subjects. Calcif Tissue Int 1984;261:S74.

8 Kanis JA. Monitoring the treatment of Paget's disease with etidronate. Calcif Tissue Int 1984;36:629-31.

9 Walton RJ, Russell RGG, Smith R. Changes in the renal and extrarenal handling of phosphate induced by disodium etidronate (EHDP) in man. Clinical Science and Molecular Medicine 1975;49:45-56.

(Accepted I October 1985) 